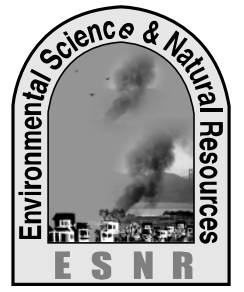

J. Environ. Sci. \& Natural Resources, 6(1): 37 - 40, 2013

ISSN 1999-7361

\title{
Efficiency of Different Dose of Zinc on Growth, Productivity and Economic Returns of Mustard in AEZ 11 of Bangladesh
}

\author{
M. G. Azam ${ }^{1}$, J. A. Mahmud ${ }^{2}$ K. U. Ahammad' ${ }^{2}$ M. A. Gulandaz ${ }^{1}$ and M. Islam ${ }^{1}$ \\ ${ }^{1}$ Regional Agricultural Research Station \\ ${ }^{2}$ On-Farm Research Division, Bangladesh Agricultural Research Institute, Jessore
}

\begin{abstract}
An experiment was carried out in the farmer's field at the MLT site Tularampur, Narail (AEZ-11) during the rabi season of 2011-12 to evaluate the performance of newly released mustard varieties to $\mathrm{Zn}$ fertilization. Three levels of zinc 2, 3 and $4 \mathrm{~kg} / \mathrm{ha}$ from zinc sulphate was used in BARI Sharisha-14. The experiment was carried out in a tree with 6 dispersed replications. Response of mustard to zinc fertilizer was significantly evident for yield. The highest yield (1.42 $\mathrm{t} / \mathrm{ha})$ was obtained from $\mathrm{T}_{1}(3 \mathrm{~kg}$ $\mathrm{Zn} / \mathrm{ha}$ ) which was statistically higher than $\mathrm{T}_{2}(4 \mathrm{~kg} \mathrm{Zn} / \mathrm{ha})$ yielding $1.37 \mathrm{t} / \mathrm{ha}$. Both the treatments gave higher yields over the control. From the economic analysis, the highest gross margin was observed (Tk. 47695/ha and Tk. 44595/ha) and highest benefit cost ratio (BCR) (1.57 and 1.45) obtained from $\mathrm{T}_{2}$ treatment followed by $\mathrm{T}_{3}$ treatment, respectively.
\end{abstract}

Key words: BCR, Dose, Mustard yield, Zn fertilizer

\section{Introduction}

Mustard is the important edible oil among the oilseeds grown all over Bangladesh. Mustard covers about 0.55 million ha of land and produces about 5.1 million tons of seeds with the average and yield is of $932 \mathrm{~kg} / \mathrm{ha}$ (DAE, 2011). It is the first position according of area and production under oilseeds in this country, but second in the world (Raymer, 2002). The present national average yield of mustard is poor $(932 \mathrm{~kg} / \mathrm{ha})$ may be attributable to proper fertilizer management practices and the local variety (Anon., 2006). Every year Bangladesh has to import a large quantity of edible oil $(11,88142$ tons in 2008 as per FAO STAT, 2009). In the High Ganges River Flood Plain (AEZ-11), the major cropping patterns are Mustard-Boro-T. aman under medium high land and Mustard-Boro rice- Fallow under medium low land.

Zinc is an essential micronutrient; deficiency of $\mathrm{Zn}$ is covering a large region in the world (Fageria et al, 2002). Sakai et al., (1997) reported that the continuous rice wheat cropping system with increasing NPK fertilizer applications is the cause of depleting the soil available micronutrients reserve, particularly of available $\mathrm{Zn}$, leading to decline in crop productivity.

Poor growth, interveinal chlorosis and necrosis of lower leaves are the common symptoms of $\mathrm{Zn}$ deficiency in field crops. Jessore region is an extensively mustard growing area and the soil of this area is calcareous in nature. So, it is expected that mustard varieties may differ in their sensitivity to $\mathrm{Zn}$ deficiencies.

Keeping the above points in view, the present study was undertaken to evaluate the response of different levels of zinc fertilizer the on yield and yield components of mustard growing in the southern part Agro-Ecological Zone 11 of Bangladesh. i.e.,

\section{Materials and Methods}

The experiment was carried out in the farmer's field at the MLT site Tularampur, Narail during the rabi season of 2011-12 under High Ganges River Flood Plain (AEZ-11). The properties of soils are given in Table 1. Three levels on zinc fertilization $(2,3$ and 4 $\mathrm{kgha}^{-1}$ ) were used in BARI Sharisa-14. The treatments were: $\mathrm{T}_{1}=\mathrm{Zn}_{2}+\mathrm{N}_{120} \mathrm{P}_{35} \mathrm{~K}_{65} \mathrm{~S}_{20} \mathrm{~B}_{1.5} \mathrm{kgha}^{-1}+$ 5 ton cowdung ha ${ }^{-1}, \mathrm{~T}_{2}=\mathrm{Zn}_{3}+\mathrm{N}_{120} \mathrm{P}_{35} \mathrm{~K}_{65} \mathrm{~S}_{20} \mathrm{~B}_{1.5}$ kgha $^{-}$ ${ }^{1}+5$ ton cowdung ha ${ }^{-1}, \mathrm{~T}_{3}=\mathrm{Zn}_{4}+\mathrm{N}_{120} \mathrm{P}_{35} \mathrm{~K}_{65} \mathrm{~S}_{20}$ $\mathrm{B}_{1.5} \mathrm{kgha}^{-1}+5$ ton cowdung ha ${ }^{-1}$ and $\mathrm{T}_{4}=0+$ $\mathrm{N}_{120} \mathrm{P}_{35} \mathrm{~K}_{65} \mathrm{~S}_{20} \mathrm{~B}_{1.5} \mathrm{kgha}^{-1}$. The experiment was laid out in a Randomized complete Block Design with 6 dispersed replications. The unit plot size was $5 \mathrm{~m} x$ $4 \mathrm{~m}$ ' maintaining a spacing of $30 \mathrm{~cm}$ between rows. Seeds were sown from 2 to 5 November 2011.The half of the urea and entire amount of other fertilizers were applied as basal and the rest half of urea was applied in two equal splits as top dressing given at 25 to 35 (DAS). Two irrigations were applied at 25 and 45 (DAS). Furadan 5G was applied @ 4 kg/ha as basal during land preparation and malathion (0. 2\%) sprayed in two installments' at 45 and 60 (DAS). The crops were also sprayed with Rovral $(0.2 \%)$ and Secure $(0.1 \%)$ ) alternately four times (at 30, 45, 60 and 75 (DAS) respectively) to prevent and/or control alternaria blight infection. The crop was harvested on 24 to 28 January 2012. Data on yield and yield contributing characters were recorded from 10 randomly selected plants. The collected data were analyzed statistically. Using M-STATprogram and the treatment means were compared by using Duncan's Multiple Range Test (DMRT) as out lined by Gomez and Gomez (1984). 
Table 1. Soil analysis values of different samples collected from Tularampur, Narail

\begin{tabular}{|c|c|c|c|c|c|c|c|c|}
\hline \multirow[t]{2}{*}{ Sites } & \multirow[t]{2}{*}{$\mathrm{pH}$} & \multirow{2}{*}{$\begin{array}{l}\mathrm{OM} \\
(\%)\end{array}$} & \multirow[t]{2}{*}{$\mathrm{K}$ meq/100g } & \multirow[t]{2}{*}{$\begin{array}{c}\text { Total } \\
\mathrm{N}(\%)\end{array}$} & $\mathrm{P}$ & $S$ & B & $\mathrm{Zn}$ \\
\hline & & & & & \multicolumn{4}{|c|}{$\frac{1}{\mu g / g}$} \\
\hline Tularampur & 7.5 & 1.39 & 0.15 & 0.09 & 28.5 & 20.4 & 0.12 & 0.80 \\
\hline Interpretation & - & - & low & Very low & optimum & Medium & Very low & Medium \\
\hline
\end{tabular}

\section{Results and Discussion}

Different yield contributing characters of mustard as influenced by treatments are presented in Table 2. By applying three levels of zinc fertilizer on mustard, it was found that yield and yield contributing characters showed significant differences among the treatments except for the plant population parameters. Highest plant height $(91.72 \mathrm{~cm})$ was found with the treatment $\mathrm{T}_{2}$ which was statistically difference among the treatments and the lowest plant height $(87.04 \mathrm{~cm})$ resulted from control or zero $\mathrm{Zn}$ fertilizer practice.

Zinc fertilizer application showed a significant increase in number of siliqua $\mathrm{ha}^{-1}$ and seeds per siliqua. It is evident that zinc element plays an important role in plants (marschner, 1995).
Diepenbrock (2000) suggested that the seed yield of individual plants is closey related to the number of siliqua per plant. The highest siliqua per plant (37.32) was obtained form the $\mathrm{T}_{2}$ treatment and lowest (27.83) obtained from the $\mathrm{T}_{4}$ treatment. Riley et al. (2000) revealed that similar increases in wheat and oilseed yield. Maximum seeds per siliqua and 1000 seeds weight ((37.28 and $3.17 \mathrm{gm})$ were produced by the $\mathrm{T}_{2}$ treatment, respectively. which was statistically differed among the treatments. Lowest seeds per siliqua (33.43) and 1000 seeds weight (2.71 gm) were observed from $\mathrm{T}_{4}$ treatment. The treatment $\mathrm{T}_{2}$ showed highest stover yield $(2.13 \mathrm{t} / \mathrm{ha})$ which was statistically similar with $\mathrm{T}_{3}$ but different from other treatments. Increasing $\mathrm{Zn}$ levels provides better conditions for the pod formation and increases no. of seeds per siliqua. The analysis of variance indicated that the application of $\mathrm{Zn}$ fertilizer significantly increased seed yield as reported by (Riley et al., 2000)

Table 2. Yield attributes of BARI Sharisha-14 at MLT site, Tularampur, Narail as affected by different levels of Zn fertilization

\begin{tabular}{l|c|c|c|c|c|c|c}
\hline Treatments & $\begin{array}{c}\text { Plant } \\
\text { height } \\
(\mathrm{cm})\end{array}$ & $\begin{array}{c}\text { Plant } \\
\text { population } \\
/ \mathrm{m}^{2}\end{array}$ & $\begin{array}{c}\text { Siliqua/ } \\
\text { plant }\end{array}$ & $\begin{array}{c}\text { Seeds/ } \\
\text { Siliqua }\end{array}$ & TSW (g) & $\begin{array}{c}\text { Stover wt. } \\
(\mathrm{t} / \text { ha })\end{array}$ & $\begin{array}{c}\text { increased over } \\
\text { control(\%) }\end{array}$ \\
\hline $\mathrm{T}_{1}$ & $87.09 \mathrm{c}$ & 79.40 & $33.33 \mathrm{~b}$ & $33.92 \mathrm{c}$ & $2.88 \mathrm{bc}$ & $1.82 \mathrm{~b}$ & 11.81 \\
\hline $\mathrm{T}_{2}$ & $91.72 \mathrm{a}$ & 82.42 & $37.32 \mathrm{a}$ & $36.28 \mathrm{a}$ & $3.17 \mathrm{a}$ & $2.13 \mathrm{a}$ & 22.73 \\
\hline $\mathrm{T}_{3}$ & $89.60 \mathrm{~b}$ & 77.83 & $34.45 \mathrm{~b}$ & $35.03 \mathrm{~b}$ & $3.00 \mathrm{~b}$ & $1.95 \mathrm{ab}$ & 18.18 \\
\hline $\mathrm{T}_{4}($ control $)$ & $87.08 \mathrm{c}$ & 75.50 & $27.83 \mathrm{c}$ & $33.43 \mathrm{c}$ & $2.71 \mathrm{c}$ & $1.75 \mathrm{bc}$ & - \\
\hline $\mathrm{CV}(\%)$ & 1.42 & 3.18 & 3.46 & 3.62 & 3.61 & 4.44 & - \\
$\mathrm{LSD}(0.05)$ & 1.634 & $\mathrm{NS}$ & 1.476 & 0.728 & 0.141 & 0.108 & - \\
\hline
\end{tabular}

Seed yield of mustard as influenced by different zinc fertilizer (Fig. 1). The highest yield (1.42 t/ha) was obtained from $\mathrm{T}_{2}(3 \mathrm{~kg} \mathrm{Zn} / \mathrm{ha})$ which was statistically higher than $\mathrm{T}_{3}(4 \mathrm{~kg} \mathrm{Zn} / \mathrm{ha})(1.37 \mathrm{t} / \mathrm{ha})$. Both the treatment performed higher yield over control. Mondal et al. (1996) reported that the highest seed yield of mustard (1.40 t/ha) was obtained from a fertilizer level of 150-90-100-30-4-1 kg/ha of $\mathrm{N}$, $\mathrm{P}_{2} \mathrm{O}_{5}, \mathrm{~K}_{2} \mathrm{O}, \mathrm{S}, \mathrm{Zn}$ and $\mathrm{B}$, respectively. Higher yield contributing characters and yields in high management were also observed by Ahmed et al. (1999). Also, seed yield reduction at pod formation was also associated with the reduction of the seeds per plant (Mendham et al., 1995). The highest yield increased over control (22.73\%) $\mathrm{T}_{2}$ treatment $18.18 \%$ and $11.81 \%$ yield increased over control obtained form $\mathrm{T}_{3}$ and $\mathrm{T}_{1}$ treatments, respectively. 


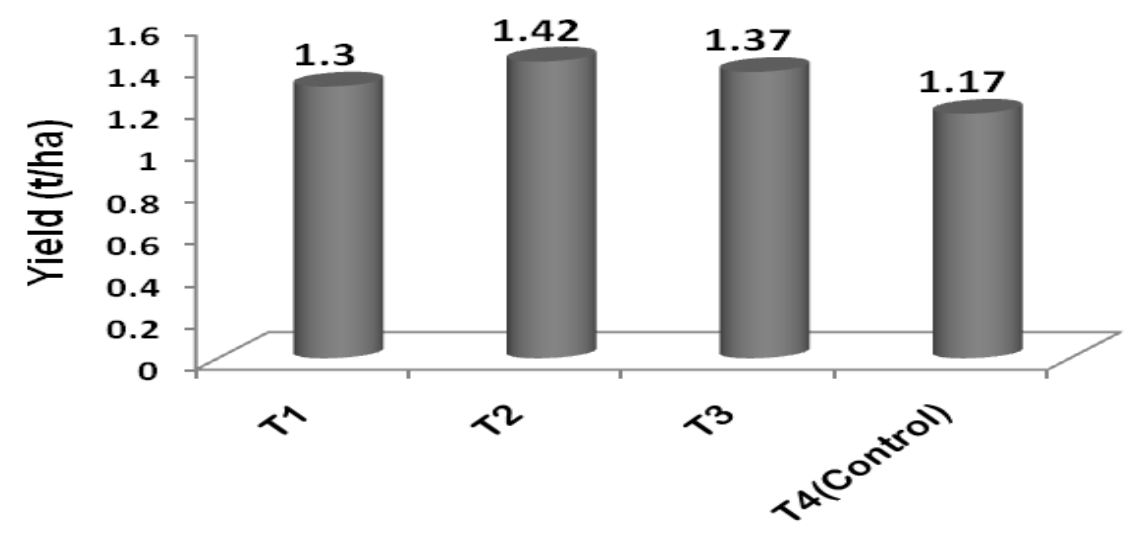

Fig 1. Mustard seed yield as influenced by zinc fertilizer

\section{Economic Performance}

Highest gross return (Tk.78100/ha) and gross margin (Tk.47695/ha) were obtained from BARI Sarisha 14 with $\mathrm{T}_{2}$ fertilizer level and also highest benefit cost ratio (BCR) was observed (1.57). Farmers fertilizer dose gave lower gross margin (Tk.36860/ha) as well as lower benefit cost ratio (1.34) with the variety under study (Fig 2).

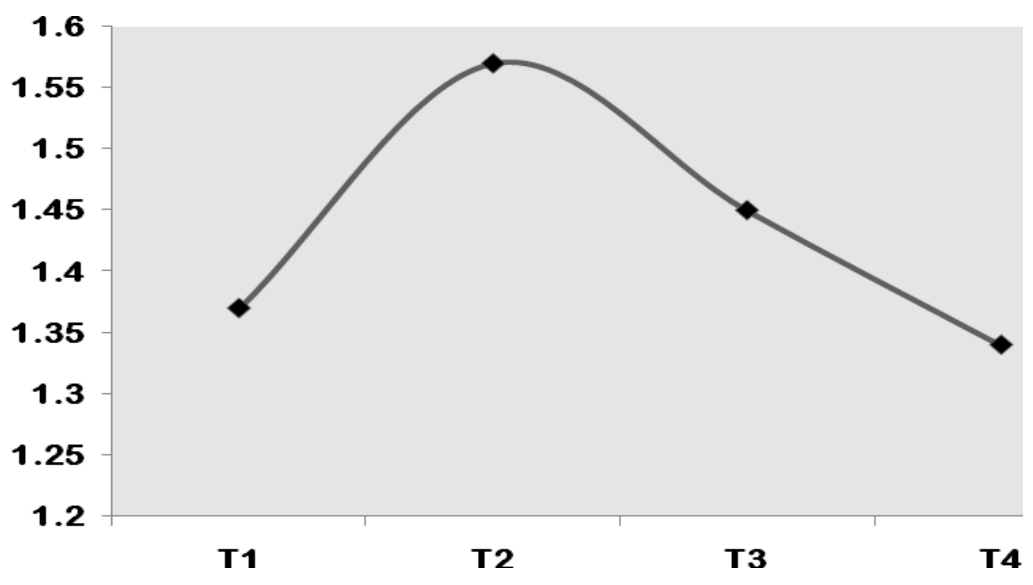

Fig 2. Schematic diagram showing BCR of fertilization in mustard

\section{Conclusions}

In summary, it is concluded that $\mathrm{Zn}$ application can affect the growth, yield and plant characters of mustard. The supplemental $\mathrm{Zn}$ is important micronutrient to control $\mathrm{Zn}$ deficiency in high and medium lands in Jessore region. The seed yield of mustard (cv. BARI Sarisha-14) increased markedly due to $\mathrm{Zn}$ application in soil, showing 11-25\% yield increases over control. In Tularampur, the yield of BARI Sarisha 14 was highest in $\mathrm{T}_{2}$ treatments i.e. application of $3 \mathrm{~kg}_{\mathrm{zinc}} \mathrm{ha}^{-1}$. So, the rate $3 \mathrm{~kg} \mathrm{Zn} \mathrm{ha}^{-1}$ was found optimum for higher seed yield of mustard.

\section{Refferences}

Ahmed, F.; Karim, M. R. and Jahan, M. A. 1999. Effect of different management practices on the productivity and profitability of mustard under late sown condition, Bangladesh $J$. Agril. Res., 24(3): 425-430.

Alam, M. M. and M. M. Rahman. 2006. Effect of row spacing on seed yield of five varieties of Rapeseed, Bangladesh J. Crop Sci., 17(1): 163-168. 
Anonymous. 2006. Bangladesh Bureau of Statistics. Monthly Statistical Bulletin of Bangladesh. January, Statistics Div., Ministry of Planning, Govt. People's Repub. Bangladesh. 54.

DAE (Department of Agricultural extension), 2011. Oil statistics. Extension Statics Retrieved May 20, 2011 from http/www.dae.gov.bd/ index.php?area $=$ statisticsaction $=$ sta_oil.html.

Diepenbrock, W. 2000. Yield analysis of winter oilseed rape (Brassica napus L.), a review. Field Crops. Res., 67: 35-49.

Fageria, N. K.; Baligar, V. C. and Clark, R. B. 2002. Micronutrients in Crop Production. $A d v$. Agron., 77: 185-268.

Gomez, K. A. and Gomez, A. A. 1984. Statistical procedures for agricultural research. John Wiley and Sons. New York, pp: 139-240.

Marschner, H. 1995. Mineral nutrition of higher plants. $2^{\text {nd }}$ Edition. Academic press. Newyork.
Mendham, N. J. and Salisbury, P. A. 1995. Physiology, crop development, groth and yield. In: Kimber, D. S and McGregor, D. I. (Ed.). Bbrassica oil seeds: Production and utilization. CAB International, London. Pp:11-64.

Mondal, M. R. I.; Fattah, Q. A.; Chaudhury, A. J.; Podder, M. H and Alam, P. M .S. (1996) Effect of fertilizers on yield and economic return of mustard. Dhaka Univ. J. Biol. Sci., 5(2): 173-177.

Raymer, P. L. 2002. Rapeseed: An Emerging Oilseed Crop. In: Trends in New Crops and New Uses, Janick, J. and A. Whipkey (Eds.). ASHS Press, Alexandria, VA., pp: 122-126.

Riley, T. G.; Zhao F. and McGrath, S. P. 2000. Available of different form of sulphur fertilizer on wheat and oil seed rape. Plant. Soil.222: 139- 147.

Sakai, R.; Nayyar, V. K.; Singh, M. V.; Biswas, T. D. and Narayanasmy, G. 1997. Micronutrients status under rice-wheat cropping system for sustainable soil productivity. Indian Soc. Soil Sci. Bull., 18: 39-47. 